\title{
Review Article \\ Some Basic Thesis of Socialism - Lenin on the State and The Applica in Vietnam
}

\author{
Pham Hong Thai* \\ VNU School of Law, Vietnam National University, Hanoi, \\ 144 Xuan Thuy, Cau Giay, Hanoi, Vietnam
}

Received 15 May 2020

Revised 20 June 2020; Accepted 27 June 2020

\begin{abstract}
The essay focuses on explaining the basic issues of Marxism - Leninism about: the nature of the state, the dictatorship of the proletariat, the socialist state, the viewpoint of organizing the exercise of power State and application into Vietnamese conditions through historical periods through analysis of Constitutional provisions and practices

Keywords: marxism - Leninism, state nature, dictatorship of the proletariat, organization of state power, manipulation, constitution, practice.
\end{abstract}

\footnotetext{
* Corresponding author.

Email address: thaihanapa201@yahoo.com) 


\title{
Những luận điểm căn bản của chủ nghĩa Mác - Lê nin về nhà nước và vận dụng ở Việt Nam
}

\author{
Phạm Hồng Thái* \\ Khoa Luật, Đaih học Quốc gia Hà Nội, 144 Xuân Thủy, Cầu Giấy, Hà Nội, Việt Nam \\ Nhận ngày 15 tháng 05 năm 2019 \\ Chỉnh sửa ngày 20 tháng 6 năm 2019; Chấp nhận đăng ngày 27 tháng 6 năm 2020
}

\begin{abstract}
Tóm tắt: bài viết tập trung luận giải những vấn đề căn bản của chủ nghĩa Mác - Lê nin về : bản chất của nhà nước, chuyên chính vô sản, về nhà nước xã hội chủ nghĩa, quan điểm tổ chức thực hiện quyền lực nhà nước và sự vận dụng vào điều kiện Việt Nam qua các giai đoạn lịch sử thông qua phân tích các quy định Hiến pháp và thực tiễn.

Tù khóa: chủ nghĩa Mác - Lê nin, bản chất nhà nước, chuyên chính vô sản, tổ chức quyền lực nhà nước, vận dụng, hiến pháp, thực tiễn.
\end{abstract}

\section{Những luận điểm căn bản của chủ nghĩa Mác - Lênin về nhà nước}

Để chỉ ra và đánh giá được sự vận dụng quan điểm của chủ nghĩa Mác - Lê nin về nhà nước vào điều kiện Việt $\mathrm{Nam}$, cần khái quát chỉ ra những luận điểm căn bản của chủ nghĩa Mác Lê nin về nhà nước. Theo V. I. Lê nin, vấn đề nhà nước: đó là vấn đề rất cơ bản, mấu chốt trong toàn bộ chính trị, đến nỗi không những trong thời đại giông tố và cách mạng trong thời đại chúng ta, mà ngay cả trong các thời đại yên tĩnh nhất, thì hằng ngày trên mọi báo chí, khi bàn đến bất cứ vấn đề kinh tế hay chính trị nào bao giờ các đồng chí cũng vấp phải câu hỏi này: nhà nước là gì, bản chất của nó là gì, vai trò của nó và thái độ của Đảng ta, Đảng đấu tranh để lật đổ chế độ tư sản, Đảng cộng sản đối với nhà nước như thế nào. Nghiên cứu, trả lời tất cả những câu hỏi này là rất lớn, trong khuôn khổ của bài viết tập trung làm rõ môt số vấn đề rất căn bản sau:i) bản chất của nhà nước; ii) quan điểm về chuyên chính vô sản, về nhà nước xã hội chủ nghĩa; iii) quan điểm tổ chức thực hiện quyền lực nhà nước và sự vận dụng vào điều kiện Việt Nam.

Một là: về bản chất nhà nước

Theo quan điểm của nhũng nhà kinh điển chủ nghĩa Mác - Lê nin, nhà nước là pham trù lịch sử và mang bản chất giải cấp, Ph. Ăngghen chỉ rõ "Vì nhà nước nảy sinh ra từ những nhu cầu phải kiềm chế những đối lập giai cấp, vì nhà nước đồng thời cũng nảy sinh ra giữa cuộc xung đột của các giai cấp, cho nên theo lệ thường, nhà nước là của giai cấp có thế lực nhất, của các giai cấp thống trị về mặt kinh tế và nhờ có nhà nước mà cũng trở thành giai cấp thống trị về chính trị...” [1].

Trên cơ sở quan điểm này, V. I, Lê nin khẳng định "nhà nuớc là sản phấm và biểu hiện của những mâu thuẫn giai cấp không thể điều hòa được. Nhà nước xuất hiện ở đâu, và khi nào mà nhũng mâu thuẫn giai cấp xét một cách khách quan không thể điều hòa đượ" [2]. Thực tiễn lịch sư đấu tranh chính trị ở các quốc gia, của nhân loại đã minh chứng rằng các giai cấp luôn

\footnotetext{
* Tác giả liên hệ.

Địa chỉ email: thaihanapa201@yahoo.com

https://doi.org/10.25073/2588-1167/vnuls.4279
} 
đấu tranh đấu tranh nhằm giành quyền thống trị xã hội, thống trị các giai cấp khác, buộc phải tuân theo ý chí của minh. Với quan điểm, thưc tiễn lịch sử nhà nước ra đời là kết quả của đấu tranh giai cấp, do vậy, nhà nước truớc hết trở thành công $c u$ để bảo vệ lợi ích của giai cấp thống trị - giai cấp thống trị về mặt kinh tế và được xã hội "thừa nhận là đại biểu chung của xã hội” [3]. Trên cơ sở quan điểm của C.Mác và $\mathrm{Ph}$.Ăng-ghen về bản chất của nhà nước, V.I.Lênin tiếp tục khẳng định, nhà nước là một hiện tượng lịch sử, sự tồn tại và tiêu vong của nó là tùy thuộc vào những điều kiện cụ thể, "nhà nước chỉ là một tổ chức thống trị của một giai cấp" [4] và "bất cú nhà nước nào cũng là một bộ máy để một giai cấp này trấn áp giai cấp khác" [5]. Trong tác phẩm "Bàn về nhà nước", V.I. Lê nin viết "nhà nước là bộ máy để duy trì sự thống trị của giai cấp này đối với giai cấp khác tách ra khỏi xã hội và bao gồm một nhóm người chỉ chuyên làm công tác cai trị” [6]. Như vậy, để thực hiện sự thống trị của mình, giai cấp thống trị đã tổ chức ra bộ máy nhà nước với đội quân chuyên nghiệp " tách ra khỏi” xã hội để thống trị xã hội, thống trị giai cấp khác. Bên cạnh đó,V.I.Lê-nin luận giải và chỉ rõ: "Nếu quyền lực chính trị trong nước nằm trong tay một giai cấp có quyền lợi phù hợp với quyền lợi của đa số, thì mới có thể thực hiện việc điều khiển công việc quốc gia thực sự theo đúng nguyện vọng của đa số. Nhưng nếu quyền lực chính trị nằm trong tay một giai cấp có quyền lợi khác với quyền lợi của đa số, thì việc điều khiển công việc quốc gia theo nguyện vọng của đa số không khỏi trở thành một sự lừa gạt, hoặc đưa đến chỗ đàn áp đa số ấy" [7]. Ông viết tiếp "Quyền chính trị là gì, nếu không phải là cách diễn đạt, là việc ghi nhận so sánh lực lượng?" [8]. Đây chính là sự phát triển quan điểm: quyền lực chính trị, theo đúng nghĩa của nó, là bạo lực có tổ chức của một giai cấp để trấn áp một giai cấp khác của C.Mác và $\mathrm{Ph}$.Ăng-ghen.

Những luận điểm nêu trên là căn cứ để khẳng định về bản chất giai cấp của nhà nước trong quan điểm của những người sáng lập chủ nghĩa Mác - Lênin. Chính bản chất giai cấp tạo nên chức năng giai cấp của nhà nước. Đây là phát kiến của những người sáng lập chủ nghĩa Mác Lê nin về bản chất giai cấp của nhà nước, mà trước đó không được đề cấp đến, hoặc được đề cập rất mờ nhạt trong quan điểm của các nhà tư tưởng. Bên cạnh chức năng giai cấp, những người sáng lập ra chủ nghĩa Mác - Lê nin cũng chỉ ra chức năng xã hội của nhà nước. C. Mác đã viết: "chức năng xã hội là cơ sở của sự thống trị chính trị, và sự thống trị chính trị cũng chỉ kéo dài chừng nào nó còn thực hiện chức năng xã hội đó của nó" [9]. Như vậy, bên cạnh chức năng giai cấp, nhà nước còn có chức năng xã hội, thực hiện chức năng xã hội là điều kiện, tiền đề để thực hiện chức năng giai cấp, khi thực hiện không tốt chức năng xã hội, giai cấp thống trị sẽ mất dẫn vai trò, chức năng thống trị của mình. Dó đó, khi thực hiện chức năng giai cấp, nhà nước - giai cấp thống trị cũng cần phải thực hiện chức năng xã hội, tính đến lợi ích của những giai cấp khác trong xã hội và giải quyết những vấn đề chung của xã hội. Chức năng giai cấp và chức năng xã hội là hai mặt của vấn đề bản chất nhà nước, mâu thuẫn nhưng thống nhất, nội dung chức năng giai cấp, chức năng xã hội của nhà nước cũng có những thay đổi trong những giai đoạn phát triển của nhà nước.

Hai là, quan điểm về chuyên chính vô sản, về nhà nước xã hội chủ nghĩa

Quan điểm về chuyên chính vô sản, về nhà nước xã hôi chủ nghĩa, xuất hiện trong các tác phẩm: Hệ tư tưởng Đức, Sự khốn cùng của triết học và trong Tuyên ngôn của Đảng Cộng sản(1848). Các tác phẩm này nêu lên quy luật đấu tranh giai cấp trong lịch sử và sự tất yếu của việc giai cấp vô sản giành lấy chính quyền. Nhưng vấn đề tổ chức chính quyền của giai cấp vô sản như thế nào chưa được giải đáp. Trong "Hệ tư tưởng Đức" mới hình thành quan điểm duy vật về nhà nước, đấu tranh giai cấp là động lực phát triển của xã hội có đối kháng giai cấp. Trong tác phẩm Tuyên ngôn của Đảng Cộng sản, C.Mác đã tiên đoán một nhà nước, một xã hội và một nền kinh tế mới. Theo ông, nhà nước là sản phẩm của cuộc chuyển biến kinh tế - xã hội. Điều này bắt đầu bằng việc xoá bỏ chính quyền của giai cấp tư sản và đập tan thượng tầng kiến trúc tư bản. Sau đó, thiết lập nên "nền chuyên chính 
vô sản, “một bộ máy nhà nước vô sản kiểu mới bộ máy nhà nước xã hội chủ nghĩa. Bộ máy nhà nước đó có các chức năng: xoá bỏ giai cấp bóc lột, bảo vệ đất nước chống ngoại xâm, dưới sự lãnh đạo của giai cấp công nhân, cải tạo xã hội chủ nghĩa trên lĩnh vực kinh tế và văn hoá, cũng như xây dựng một xã hội không có giai cấp.

Dựa vào kinh nghiệm của cuộc cách mạng 1848 và của giai đoạn lịch sử 1848 - 1851 ở Pháp, C.Mác đã đưa ra lý luận là cần phải "đập tan bộ máy nhà nước tư sản" trong quá trình làm cách mạng vô sản, chứ không phải tiếp tục bộ máy đó để phục vụ cho lợi ích của giai cấp mới. Tổng kết kinh nghiệm của Công xã Pari (1871), Mác nhận định rằng nhà nước vô sản phải là kiểu công xã Pari, tức là nhà nước kiểu mới, được trình bày trong tác phẩm "Nội chiến ở Pháp". Do yêu cầu đấu tranh cách mạng và để hoàn chỉnh học thuyết của mình, những nhà sáng lập ra chủ nghĩa Mác đã mở rộng phạm vi và đi sâu nghiên cứu nhiều vấn đề khác về nhà nước; vấn đề phát sinh nhà nước đầu tiên trong xã hội có giai cấp, vấn đề nhà nước tiêu vong. Ph.Ănghen trình bày những tư tưởng này trong tác phẩm: "Nguồn gốc của gia đình, của chế độ tư hữu và của nhà nước" (1884 - 1891).

Trong điều kiện chủ nghĩa tư bản đã trở thành chủ nghĩa đế quốc và cách mạng vô sản, V.I. Lê nin là người đã phát triển học thuyết của Mác - Ănghen về nhà nước. V.I. Lênin đã đấu tranh chống sự xuyên tạc của bọn cải lương, xét lại, vô Chính phủ, đồng thời vận dụng quan điểm về nhà nước của $\mathrm{C}$. Mác và $\mathrm{Ph}$. Ănghen vào thực tiễn cách mạng của nước Nga năm 1917, viết tác phẩm nổi tiếng "Nhà nước và cách mạng", trực tiếp giảng bài "Bàn về nhà nước" ở Trường đại học Svéc-lốp.Trên cơ sở những luận điểm của C.Mác và $P h$.Ăngghen về nhà nước, bản chất của nhà nước, trong điều kiện giai cấp công nhân đã giành được chính quyền, V.I.Lênin chỉ rõ phải xây dựng một nhà nước kiểu mới - nhà nước chuyên chính vô sản với hai chức năng cơ bản là trấn áp và tổ chức xây dựng xã hội mới. Người viết "Bây giờ chúng ta sẽ xây dựng, trên một miếng đất đã dọn sạch những di vật đổ nát của lịch sử, tòa lâu đài xã hội xã hội chủ nghĩa, đồ sộ và rực rỡ; sẽ thiết lập nên một nhà nước kiểu mới chưa từng có trong lịch sử, một nhà nước thể theo ý chí của cách mạng mà có nhiệm vụ quét sạch khỏi mặt đất mọi sự bóc lột, mọi bạo lực, mọi sự nô dịch" [10]. Với cách nhìn biện chứng, thực tiễn lịch sử xã hội đã từng có giai đoạn không có nhà nước, về sự ra đời của nhà nước, bằng lịch sử sự thay thế giữa các kiểu nhà nước trong lịch sử, nguyên nhân sự thay đổi các kiểu nhà nước V.I.Lê-nin viết: "Mục đích cuối cùng mà chúng ta theo đuổi, là thủ tiêu nhà nước, nghĩa là thủ tiêu mọi bạo lực có tổ chức và có hệ thống, mọi bạo lực, nói chung, đối với con người. Chúng ta không mong có một chế độ xã hội mà trong đó nguyên tắc thiểu số phục tùng đa số sẽ không được tuân theo. Nhưng khi hướng đến chủ nghĩa xã hội, chúng ta tin chắc rằng chủ nghĩa xã hội sẽ chuyển thành chủ nghĩa cộng sản, và do đó, nói chung sẽ không còn cần thiết phải dùng bạo lực đối với con người, không cần thiết phải buộc người này phục tùng người khác, bộ phận dân cư này phuc tùng bộ phận dân cư khác, vì người ta sẽ quen tuân theo những điều kiện thông thường của đời sống tập thể, mà không cần có bạo lực và không cần có phuc tùng" [11]. Nghĩa là, khi đó nhà nước sẽ tự tiêu vong. Tuy nhiên, để nhà nước có thể tự tiêu vong, cần có nhiều điều kiện, trong đó, quan trọng nhất là, nhà nước phải trải qua một hình thức tồn tại đặc biệt của nó: Nhà nước chuyên chính vô sản. Nhưng để có được nhà nước chuyên chính vô sản, tất yếu phải dùng đến bạo lực cách mạng. V.I. Lê-nin chỉ rõ: "Không có cách mạng bạo lực thì không thể thay nhà nước tư sản bằng nhà nước vô sản được. Việc thủ tiêu nhà nước vô sản, nghĩa là việc thủ tiêu mọi nhà nước, chỉ có thể thực hiện được bằng con đường "tiêu vong" thôi" [12]. Bạo lực cách mạng là phương thức duy nhất để một giai cấp mới, tiến bộ giành lấy quyền lực chính trị. Điều đó đúng đối với giai cấp vô sản và hơn thế, với giai cấp vô sản, bạo lực cách mạng còn phải thực hiện một nhiệm vụ quan trọng nữa, đó là đập tan bộ máy nhà nước cũ để xây dựng nhà nước kiểu mới. Đập tan bộ máy nhà nước cũ để xây dựng nhà nước chuyên chính vô sản, nhà nước chuyên chính vô sản là hình thức nhà nước chuyển tiếp trước khi đạt đến trạng thái tiêu vong của nhà nước. Về điều này, được V.I. Lê nin luận 
giải, làm rõ khi phân tích mối quan hệ biến chứng giữa chuyên chính vô sản và tính dân chủ của nhà nước. Trước hết, V.I.Lê-nin khẳng định, "trong thời kỳ quá độ từ chủ nghĩa tư bản lên chủ nghĩa cộng sản, sự trấn áp vẫn còn tất yếu, nhưng nó đã là sự trấn áp của đa số bị bóc lột đối với thiểu số bóc lột. Cơ quan đặc biệt, bộ máy trấn áp đặc biệt là "nhà nước" vẫn còn cần thiết, nhưng nó đã là nhà nước quá độ, mà không còn là nhà nước theo đúng nghĩa của nó nữa"[13] và nhà nước vô sản phải là một công cụ, một phương tiện; đồng thời, là một biểu hiện tập trung trình độ dân chủ của nhân dân lao động.

Bên cạnh những quan điểm về “ chuyên chính vô sản, V.I. Lê nin cũng nhấn mạnh vấn đề dân chủ trong điều kiện chủ nghĩa xã hội, dân chủ trong xã hội xã hội chủ nghĩa chính là nhân dân tham gia vào mọi công việc của nhà nước. Người viết: "Điều cần thiết không phải chỉ là cơ quan đại biểu theo kiểu chế độ dân chủ, mà là toàn bộ việc quản lý nhà nước từ dưới lên phải do bản thân quần chúng tổ chức, quần chúng thực sự tham gia vào từng bước của cuộc sống và đóng vai trò tích cực trong việc quản lý" 14]. V.I. Lê-nin cho rằng, nếu tính giai cấp là bản chất của mọi nhà nước, thì dân chủ hay chuyên chính cũng chỉ là hai mặt của bản chất đó mà thôi. "Bất cứ một nhà nước nào cũng đều có nghĩa là dùng bạo lực; nhưng toàn bộ sự khác nhau là ở chỗ dùng bạo lực đối với những người bị bóc lột hay đối với kẻ đi bóc lột, ở chỗ có dùng bạo lực đối với giai cấp những người lao động và những người bị bóc lột không" [15]. Đối với V.I. Lênin: "Chuyên chính cách mạng của giai cấp vô sản là một chính quyền do giai cấp vô sản giành được và duy trì bằng bạo lực đối với giai cấp tư sản..." [16]. Chuyên chính vô sản không hề đối lập với dân chủ, mà là phần bổ sung, là hình thức thể hiện của dân chủ. "Chuyên chính vô sản, nghĩa là việc tổ chức đội tiền phong của những người bị áp bức thành giai cấp thống trị để trấn áp bọn áp bức, thì không thể giản đơn đóng khung trong việc mở rộng chế độ dân chủ được. Đồng thời với việc mở rộng rất nhiều chế độ dân chủ - lần đầu tiên biến thành chế độ dân chủ cho người nghèo, chế độ dân chủ cho nhân dân chứ không phải cho bọn nhà giàu - chuyên chính vô sản còn thực hành một loạt biện pháp hạn chế quyền tự do đối với bọn áp bức, bọn bóc lột, bọn tư bản" [17]. Về dân chủ trong xã hội chủ nghĩa, Người viết "Dân chủ cho tuyệt đại đa số nhân dân và trấn áp bằng vũ lực bọn bóc lột, bọn áp bức nhân dân, nghĩa là tước bỏ dân chủ đối với bọn chúng: đó là sự biến đổi của chế độ dân chủ trong thời kỳ quá độ từ chủ nghĩa tư bản lên chủ nghĩa cộng sản" [18]. Chính vì sự kết hợp giữa chuyên chính và dân chủ của nhân dân đã làm cho nhà nước xã hội chủ nghĩa không còn là nhà nước theo nguyên nghĩa của nó, đã trở thành “ nhà nước một nửa nhà nước" - sự tiêu vong của nhà nước thể hiện ở chính điều này, tùy thuộc vào sự phát triển của dân chủ trong đời sống nhà nước, xã hội, sự tham gia của nhân dân vào đời sống nhà nước và xã hội.

Như vậy, sự phát triển của V.I. Lê-nin đối với quan điểm của $C$.Mác và $\mathrm{Ph}$. Ăngghen về nhà nước, điểm quan trọng nhất chính là ở chỗ, đặc tính phổ biến của mọi nhà nước đó là tính giai cấp, trong suốt quá trình phát triển của xã hội loài người chuyên chính và dân chủ là hai mặt của mối quan hệ biện chứng. Trên phương diện này, nhà nước là một cách thức tổ chức đời sống xã hội, một giai đoạn trong tiến trình phát triển của xã hội, là một vòng khâu của sự phát triển. Đây chính là quan niệm duy vật và biện chứng có tính nguyên tắc trong việc lý giải đời sống xã hội nói chung, vấn đề nhà nước nói riêng và gắn liền với những cố gắng to lớn của V.I.Lê-nin trong sự phát triển chủ nghĩa Mác.

Ba là, quan điểm tổ chức quyền lực nhà nước

Bên cạnh sự thừa nhận sự độc lập của quyền lực hành pháp/hành chính cồng của bộ máy thư lại, nhưng khi tiếp cận quyền lực nhà nước từ khía cạnh chính trị, C.Mác dưỡng như đoạn tuyệt với tư tưởng phân quyền, ông viết " Vào một thời kỳ và ở một nước mà thế lực vua chúa, giai cấp quý tộc và giai cấp tư sản tranh giành nhau quyền thống trị, mà do đó quyền thống trị bị phân chia thì học thuyết phân quyền tỏ ra là tư tưởng thống trị, nó được người ta coi là "quy luật vĩnh viễn" [19]. Như vậy, theo ông nguyên tắc phân quyền chỉ tồn tại khi có sự tranh giành quyền lực giữa các thế lực chính trị xã hội khác nhau. Mỗi thế 
lực đều cố giành lấy một bộ phận quyền lực. Với quan điểm chính trị, C. Mác đã phê phán quan điểm phân quyền trong Hiến pháp nước Pháp sau cách mạng 1848, Ông viết " Mỗi điều khoản của Hiến pháp đều chứa sẵn trong bản thân nó cái phản đề của bản thân nó, cái Thượng viện và Hạ viện của nó: tự do trong câu nói chung chung và xóa bỏ cái tự do trong điều khoản kèm theo" [20] . " Hiến pháp đã thảo ra sao cho Quốc hội có thể gạt bỏ được tổng thống bằng con đường hợp hiến, nhưng tổng thống lại chỉ có thể bãi bỏ quốc hội bằng con đường không hợp hiến, bằng cách thủ tiêu luôn cả Hiến pháp. Như thế, là ở đây, bản thân Hiến pháp lại đi thách thức thủ tiêu mình bằng bạo lực. Chẳng những nó thần thánh hóa chế độ phân quyền giống như Hiến chương năm 1830, mà nó còn mở rộng cho chế độ phân quyền đến chỗ mâu thuẫn không sao chịu nổi... Nếu Hiến pháp giao cho tổng thống quyền thực tế, thì nó lại cố gắng bảo đảm cho quốc hội quyền lực tinh thần" [21]. Theo ông, thuyết phân quyền được áp dụng như sau: Nghị viện chỉ là nơi "bàn cãi xuông", tòa án chỉ độc lập giả dối, còn toàn bộ quyền lực tập trung vào cơ quan hành pháp.

Từ sự phủ nhận lý thuyết phân quyền ở khía cạnh chính trị, trên cơ sở kinh nghiệm Công xã Pari, C. Mác đã đưa ra quan niệm mới về tổ chức thực hiện quyền lực nhà nước của nhà nước kiểu mới. Ông viết, "Công xã Pari không phải là cơ quan đại nghị, mà là một tập thể hành động vừa lập pháp vừa hành pháp" [22]. V. I. Lê nin đã kế thừa và phát triển tư tưởng này của $\mathrm{C}$. Mác, coi đó là cơ sở lý luận của quá trình tổ chức quyền lực nhà nước kiểu mới và trên cơ sở kinh nghiệm của cách mạng 1905 ở nước Nga, Ông viết "Những cơ quan đại diện vẫn còn nhưng chế độ đại nghị với tư cách là một hệ thống đặc biệt, một sự phân chia giữa công tác lập pháp và hành pháp được coi là địa vị đặc quyền của các nghị sỹ thì không còn nữa" [23]. Như vậy, ở đây cả C. Mác và V.I. Lênin đã khẳng định quan điểm về sự thống nhất giữa lập pháp và hành pháp - sự thống nhất của quyền lực nhà nước, sự thống nhất nội tại bởi tính xã hội, tính nhân dân, tính giai cấp của nó trong điều kiện mà tất cả quyền lực nhà nước thuộc về nhân dân. Sự thống nhất, xích lại gần nhau giữa quyền lập pháp và hành pháp không phải là sự "nhập cục" tất cả quyền lực đó và trao cho một cơ quan thực hiện, mà do nhiều cơ quan thực hiện. Về nguyên tắc quyền lực thuộc về chính quyền nhân dân, nhưng quyền lập pháp được trao cho cơ quan đại diện nhân dân thực hiện, còn quyền hành pháp trao cho cơ quan chấp hành của cơ quan đại diện, nhưng chúng thống nhất với nhau về bản chất, mục tiêu và không trở thành lực cản, đối lập nhau trong hoạt động. Các cơ quan này đều là những cơ quan đại diện của nhân dân, nhân dân thực hiện quyền lực của mình thông qua các cơ quan đó, mỗi cơ quan không phải là những lực lượng đại diện cho những lực lượng, giai cấp khác nhau trong xã hội.

\section{Sụ̂ vận dung quan điểm của chủ nghĩa Mác - Lê nin về nhà nước}

Việc vận dụng quan điểm của chủ nghĩa Mác - Lê nin về nhà nước được thể hiện trong các văn kiện của Đảng cộng sản Việt Nam qua các giai đoạn, nhưng rõ nét nhất là trong các Hiến pháp Việt Nam năm 1946, 1959, 1980,1992 (đã được sửa đổi, bổ sung năm 2001) và Hiến pháp năm 2013 và thực tiễn thực hiện. Vì vậy, phần này tập trung phân tích các quy định của Hiến pháp theo những nội dung đã trình bày về quan điểm của chủ nghĩa Mác - Lê nin về nhà nước để tìm ra mối liên hệ.

Một là, về bản chất nhà nước, về chuyên chính vô sản, nhà nước xã hội chủ nghĩa

Vấn đề quan trọng nhất của Hiến pháp là vấn đề quyền lực nhà nước thuộc về ai, tổ chức thực hiện quyền lực đó bằng phương thức nào. Tất cả các Hiến pháp Việt Nam đều khẳng định quan điểm quyền lực nhà nước thuộc về nhân dân, nhưng mỗi hiến pháp có những thể hiện khác nhau. Hiến pháp năm 1946 khẳng định quan điểm "Tất cả quyền bính trong nước là của toàn thể nhân dân Việt Nam, không phân biệt nòi giống, gái trai, giàu nghèo, giai cấp, tôn giáo". Như vậy, cơ sở của chính quyền là của toàn thể nhân dân, mà không thuộc về bất kỳ giai cấp nào. Rõ ràng tính dân chủ của nhà nước được thể hiện rất rõ ràng, đậm nét, phù hợp với bối cảnh mới 
giành chính quyền và để tập hợp mọi lực lượng xã hội. Đến Hiến pháp năm 1959, lần đầu tiên sử dụng thuật ngữ quyền lực „Tất cả quyền lực trong nước Việt Nam dân chủ cộng hoà dều thuộc về nhân dân. Nhân dân sử dụng quyền lực của mình thông qua Quốc hội và Hội đồng nhân dân các cấp do nhân dân bầu ra và chịu trách nhiệm trước nhân dân“. Hiến pháp 1980: Ở nước Cộng hoà xã hội chủ nghĩa Việt Nam, tất cả quyền lực thuộc về nhân dân. Nhân dân sử dụng quyền lực nhà nước thông qua Quốc hội và Hội đồng nhân dân các cấp do nhân dân bầu ra và chịu trách nhiệm trước nhân dân. Hiến pháp 1992: tất cả quyền lực nhà nước thuộc về nhân dân mà nền tảng là liên minh giai cấp công nhân với giai cấp nông dân và tầng lớp trí thức. Hiến pháp năm 2013: tất cả quyền lực nhà nước thuộc về Nhân dân mà nền tảng là liên minh giữa giai cấp công nhân với giai cấp nông dân và đội ngũ trí thức. Như vậy, về cội nguồn quyền lực nhà nước trong các Hiến pháp đều được khẳng định thuộc về nhân dân, nhưng từ Hiến pháp 1992 và Hiến pháp năm 2013 chỉ khẳng định quyền lực nhà nước thuộc về nhân dân. Nếu so sánh giữa các Hiến pháp, có thể nhận thấy cơ sở xã hội của nhà nước có phần thu hẹp bởi tính giai cấp của nhà nước qua các Hiến pháp. Từ điều này có thể suy ra rằng, tư tưởng về nền chuyên chính vô sản đã dần được thể hiện qua các Hiến pháp.

Bên cạnh đó cũng cần nhận thất rằng, việc lựa chọn mô hình tổ chức bộ máy nhà nước theo chế độ cộng hòa - kiểu Công xã, kiểu Xô viết, quyền lực nhà nước cả lập pháp và hành pháp tập trung vào thiết chế đại biểu của nhân dân là Nghị viện/ Quốc hội và Hội đồng nhân dân ở các địa phương. Cơ quan đại biểu bầu ra cơ quan hành chính nhà nước tương ứng, do đó cơ quan hành chính nhà nước thực chất là cơ quan chấp hành, cơ quan thường trực của cơ quan đại diện.

Về sự lãnh đạo của Đảng - một điều kiện tiên quyết để xây dựng chủ nghĩa xã hội. Lần đầu tiên trong lời nói đầu của Hiến pháp năm 1959, trên cơ sở tổng kết lịch sử đã khẳng định vai trò lãnh đạo của Đảng cộng sản Đông Dương (nay là Đảng cộng sản Việt Nam) của giai cấp công nhân từ năm 1930, từ khi Đảng ra đời, đồng thời khẳng đinh con đường của cách mạng Việt Nam là tiến lên chủ nghĩa xã hội. Những quy định này của Hiến pháp là sự tiếp thu, vận dụng sáng tạo quan điểm của $C$. Mác và Lê nin về chủ nghĩa xã hội , về sự lãnh đạo của Đảng trong chủ nghĩa xã hội. Về sự lãnh đạo của Đảng đối với nhà nước và xã hội, nếu Hiến pháp năm 1959 về sự lãnh đạo của Đảng chỉ được khái quát ở lời nói đầu, đển Hiến pháp năm 1980, với quan điểm thực hiện nền chuyên chính vô sản được thể hiện rõ tại nét nhất tại Điều 4 Hiến pháp ,, Đảng cộng sản Việt Nam, đội tiên phong và bộ tham mưu chiến đấu của giai cấp công nhân Việt Nam, được vũ trang bằng học thuyết Mác - Lê nin, là lực lượng duy nhất lãnh đạo Nhà nước, lãnh đạo xã hội“. Trong Hiến pháp năm 1992, Hiến pháp 2013 về sự lãnh đạo của Đảng đều được ghi nhận thành một điều với những bổ sung nội dung ngày một hoàn thiện hơn. Đặc biệt về địa vị pháp lý của Đảng Cộng sản Việt Nam, ngoài việc tiếp tục xác định vai trò lãnh đạo nhà nước và xã hội của Đảng, Hiến pháp năm 2013 đã bổ sung thêm khoản 2 quy định: "Đảng Cộng sản Việt Nam gắn bó mật thiết với nhân dân, phục vụ nhân dân, chịu sự giám sát của nhân dân, chịu trách nhiệm trước nhân dân về những quyết định của mình". Đồng thời bên cạnh việc quy định "Các tổ chức của Đảng hoạt động trong khuôn khổ Hiến pháp và pháp luật" như Hiến pháp năm 1992, Hiến pháp 2013 đã quy định bổ sung “các đảng viên Đảng cộng sản Việt Nam hoạt động trong khuôn khổ Hiến pháp và pháp luật”. Các quy định mới này của Hiến pháp năm 2013 là hợp lý và cần thiết, phù hợp với quan điểm xây dựng nhà nước pháp quyền xã hội chủ nghĩa. Bên cạnh đó bản chất nhà nước, về chế độ chính trị ở Việt Nam được phản ánh qua các Hiến pháp chuyển từ dân chủ nhân dân ở Hiến pháp năm 1946, Hiến pháp năm 1959 như là bước quá độ đến $=>$ chuyên chính vô sản ở Hiến pháp năm 1980. Nhà nước Việt Nam dân chủ cộng hòa được đổi tên thành Nhà nước Cộng hòa Xã hội chủ nghĩa Việt Nam, trong đó công khai khẳng định Nhà nước Cộng hòa xã hội chủ nghĩa Việt Nam là „Nhà nước chuyên chính vô sản" và ,, người chủ tập thể là nhân dân lao động bao gồm giai cấp công nhân, giai cấp nông dân tập thể, tầng lớp trí thức xã hội chủ nghĩa và những người lao động khác, mà 
nòng cốt là liên minh công nông, do giai cấp công nhân lãnh đạo“. Những quy định này của Hiến pháp khẳng định tính chuyên chính của nhà nước, với quan điểm thực hiện nền chuyên chính vô sản, và xây dựng chủ nghĩa xã hội, về chế độ kinh tế, Hiến pháp năm 1980 quy định "xây dựng chủ nghĩa xã hội, về kinh tế,, từ sản xuất nhỏ tiến thẳng lên chủ nghĩa xã hội, bỏ qua giai đoạn phát triển tư bản chủ nghĩa" xây dựng một nền kinh tế quốc dân chủ yếu có hai thành phần: thành phần kinh tế quốc doanh thuộc sở hữu toàn dân và thành phần kinh tế hợp tác xã thuộc sở hữu tập thể của nhân dân lao động... kinh tế quốc doanh giữ vai trò chủ đạo trong nền kinh tế quốc dân và được phát triển ưu tiên.

Trong thực tiễn cách mạng Việt Nam qua các trong giai lịch sử với quan điểm xây dựng chủ nghĩa xã hội, trước hết phải , đập tan bộ máy nhà nước cũ “ bằng cách tước đoạt cơ sở, điều kiện kinh tế của lực lượng cũ, tính chuyên chính của nhà nước đề cao, được thể hiện qua những chính sách cụ thể của Chính phủ như chính sách cải cách ruộng đất, bằng việc ban hành Luật cải cách ruộng đất năm 1953: tịch thu, trưng thu, trưng mua ruộng đất của những đối tượng là thực dân Pháp và đế quốc xâm lược; địa chủ việt gian, phản động, cường hào gian ác; của nhân sĩ, địa chủ kháng chiến, địa chủ thường; xóa bỏ nợ mà nông dân lao động và các tầng lớp nghèo ở nông thôn đã vay của địa chủ. Hệ quả của cải cách ruộng đât với những sai lầm trong thực tiễn thực hiện dẫn đến trong xã hội ở nông thôn Việt Nam thành các giai cấp: địa chủ, trung nông, bần nông, cố nông. Ở các thành phố áp dụng Chính sách cải tạo công thương ở Miền bắc từ 1958 - 1960. Chính sách cải tạo xã hội chủ nghĩa đối với thương nghiệp tư nhân ở các tỉnh phía Nam (quyết định số 100, ngày 12/ 1977 của Chính phủ).

Với những quan điểm trong Hiến pháp và cơ chế kế hoạch hóa tập trung, quan liêu bao cấp, những nóng vội chủ quan, duy ý chí, năng lực quản lý yếu kém và những sai lầm trong thực hiện các chính sách đó cộng với chiến tranh biên giới, sự bao vây cấm vận của đế quốc Mĩ, đã dẫn tới sự khủng hoảng kinh tế vào đầu những năm tám mươi thế kỷ XX. Hệ quả đó là sự ấu trĩ, duy ý chí, chủ quan, vận dụng những quan điểm của chủ nghĩa Mác - Lê nin về nhà nước, về chủ nghĩa xã hội một cách máy móc, giáo điều, khi chưa có đầy đủ điều kiện, tiền đề kinh tế bảo đảm cho công cuộc xây dựng xã hội chủ nghĩa. Thực tiễn minh chứng rằng, không thể xây dựng chủ nghĩa xã hội với „, mo cơm nắm, quả cà “với tấm lòng cộng sản mà đi lên chủ nghĩa xã hội.

Trước tình trạng đó, để khắc phục những bất cập của đời sống kinh tế - xã hội ở nước ta, đưa đất nước khỏi khủng hoảng kinh tế, sửa chữa những sai lệch trong vận dụng quan điểm của chủ nghĩa Mác - Lê nin về nhà nước, về xã hội chủ nghĩa, trên cơ sở quan điểm đổi mới của Đảng do Đại hội đại biểu toàn quốc lần thứ sáu đề ra, Hiến pháp năm 1992 được ban hành thay thế cho Hiến pháp năm 1980, vốn được quan niệm là Hiến pháp của thời kỳ quá độ lên chủ nghĩa xã hội. Về bản chất nhà nước vẫn trên cơ sở kế thừa quan điểm của các Hiến pháp trước đó, Hiến pháp năm 1992 tiếp tục khẳng định „Nhà nước Cộng hoà xã hội chủ nghĩa Việt Nam là Nhà nước của nhân dân, do nhân dân, vì nhân dân. Tất cả quyền lực Nhà nước thuộc về nhân dân mà nền tảng là liên minh giai cấp công nhân với giai cấp nông dân và tầng lớp trí thức" " Đảng cộng sản Việt Nam, đội tiên phong của giai cấp công nhân Việt Nam, đại biểu trung thành quyền lợi của giai cấp công nhân, nhân dân lao động và của cả dân tộc, theo chủ nghĩa Mác - Lê Nin và tư tưởng Hồ Chí Minh, là lực lượng lãnh đạo Nhà nước và xã hội“", nhưng về chế độ kinh tế có những thay đổi căn bản, Nhà nước phát triển nền kinh tế hàng hoá nhiều thành phần theo cơ chế thị trường có sự quản lý của Nhà nước, theo định hướng xã hội chủ nghĩa. Cơ cấu kinh tế nhiều thành phần với các hình thức tổ chức sản xuất, kinh doanh đa dạng dựa trên chế độ sở hữu toàn dân, sở hữu tập thể, sở hữu tư nhân, trong đó sở hữu toàn dân và sở hữu tập thể là nền tảng“". Nhờ những đổi mới về chế độ kinh tế đã giải phóng được lực lượng sản xuất xã hội làm thay đổi dần mọi mặt đời sống xã hội. Từ những quy định của Hiến pháp năm 1980 đến Hiến pháp năm 1992 (đã được sửa đổi, bổ sung năm 2001) có thể khẳng định xây dựng chủ nghĩa xã hội là đinh hướng, là tất yếu của cách mạng Việt Nam, 
nhưng tính giáo điều, máy móc về chủ nghĩa xã hội đã dần được khắc phục, đây là điểm mốc quan trọng đánh dấu sự sáng tạo trong vận dụng chủ nghĩa Mác - Lề nin của Đảng và Nhà nước ta.

Trước những thay đổi của tình hình trong nước, khu vực và quốc tế, Hiến pháp năm 1992 , tuy đã được sửa đổi, bổ sung, nhưng nhiều nội dung trở nên không còn phù hợp. Trước đòi hỏi đó, Hiến pháp năm 2013 đã được ban hành với nhiều nội dung mới, thể hiện tư duy mới đã vận dụng sáng tạo chủ nghĩa Mác - Lê nin vào điều kiện hiện nay. Về bản chất của nhà nước vẫn được khẳng định như các Hiến pháp trước đây, nhưng về hình thức thực hiện quyền lực nhân dân có sự thay đổi căn bản, thể hiện sự phát triển những luận điểm căn bản của chủ nghĩa Mác Lê nin về dân chủ xã hội chủ nghĩa. Điều 6 Hiến pháp năm 2013 quy định: "Nhân dân thực hiện quyền lực nhà nước bằng các biện pháp dân chủ trực tiếp và dân chủ đại diện thông qua Quốc hội, Hội đồng nhân dân và các cơ quan nhà nước khác". Quy định này của Hiến pháp năm 2013 thể hiện sự tiến bộ rõ ràng của tư duy lập hiến Việt Nam. Tất cả các Hiến pháp trước đó, trừ Hiến pháp 1946, chỉ mới quy định các hình thức dân chủ đại diện, còn Hiến pháp năm 2013 đã quy định đầy đủ hai hình thức dân chủ trực tiếp và dân chủ đại diện trong Hiến pháp.

Bản chất giai cấp và bản chất xã hội của nhà nước còn được thể hiện ở chế độ kinh tế - cơ sở kinh tế của nhà nước, Hiến pháp 2013 quy định: Nền kinh tế Việt Nam là nền kinh tế thị trường định hướng xã hội chủ nghĩa với nhiều hình thức sở hữu, nhiều thành phần kinh tế; kinh tế nhà nước giữ vai trò chủ đạo. Đây là sự sáng tạo chưa từng có trong lịch sử xây dựng xã hội chủ nghĩa của các nước xã hội chủ nghĩa trước đây. Những thay đổi về chế độ kinh tế trong Hiến pháp là cơ sở hiến định cho những thay đổi chính sách, thể chế kinh tế, tạo cơ sở pháp lý cho sự phát triển kinh tế - xã hội, đời sống của nhân dân ngày một được nâng cao, gia nhập ngày càng sâu, rộng vào các quan hệ quốc tế, vị thế của Nhà nước ta ngày càng được khẳng định, nâng cao.
Hai là, về phương thức thực hiện quyền lực nhà nước

Về phương thức tổ chức quyền lực thực hiện quyền lực nhà nước, trên cơ sở quan của Chủ nghĩa Mác - Lê nin về tổ chức thực hiện quyền lực nhà nước, trước hết ở quan điểm về sự thống nhất của quyền lực, nhưng mỗi Hiến pháp có cách tiếp cận, giải quyết vấn đề này một cách khác nhau. Hiến pháp năm 1946, có cách tiếp cận khá lý thú, toàn diện cả về khía cạnh chính trị, xã hội và khía cạnh kỹ thuật tổ chức. Hiến pháp quy định: Điều 22 Hiến pháp năm 1946 quy định: "Nghị viện nhân dân là cơ quan có quyền cao nhất của nước Việt Nam dân chủ cộng hòa", đến điều 43 quy định: Cơ quan hành chính (hành pháp) cao nhất của toàn quốc là Chính phủ Việt Nam dân chủ cộng hòa, Điều 63 " Cơ quan tư pháp của nước Việt Nam dân chủ cộng hòa gồm có: Tòa án tối cao, các toà án phúc thẩm, các tòa án đệ nhị cấp và sơ cấp. Như vậy, trong cơ cấu quyền lực gồm các quyền lập pháp, hành pháp và tư pháp, mỗi nhánh quyền lực do một loại thiết chế nhà nước thực hiện. Như vậy, ở đây đã có sự phân biệt giữa lập pháp, hành pháp và tư pháp, đồng thời khẳng định sự độc lập giữa các thiết chế quyền lực nhà nước. Thêm vào đó, cơ chế "cân bằng quyền lực" được hình thành trong Hiến pháp khi quy định định thẩm quyền cụ thể của các cơ quan cao nhất của nhà nước Hiến pháp đã tạo nên cơ chế cơ chế " kiềm chế quyền lực" giữa các nhánh quyền lực nhà nước, đặc biệt là giữa lập pháp và hành pháp. Hiến pháp quy định "Chủ tịch nước không phải chịu một trách nhiệm nào, trừ khi phạm tội phản quốc"; "Mỗi khi truy tố Chủ tịch, Phó Chủ tịch hay một nhân viên Nội các về tội phản quốc, Nghị viện sẽ lập một toà án đặc biệt để xét xử" Điều 51 . Hiến pháp 1946 không quy định trách nhiệm của Chủ tịch nước trước nghị viện nhân dân. Trong quan hệ với Nghị viện, Điều 31 quy định" Những luật đã đự̛ơ Nghị viện biểu quyết, Chủ tịch nước Việt Nam phải ban bố chậm nhất là 10 hôm sau khi nhận được thông tri. Nhưng trong hạn ấy, Chủ tịch nước có quyền yêu cầu Nghị viện thảo luận lại. Những luật đem ra thảo luận lại, nếu vẫn được Nghị viện ưng thuận thì bắt buộc Chủ tịch phải ban bố". Nghị viện có quyền biểu quyết tín 
nhiệm Nội các, nhưng trong hạn 24 giờ sau... Chủ tịch nước có quyền đưa vấn đề tín nhiệm ra nghị viện thảo luận lại... nếu Nội các mất tín nhiệm phải từ chức".

Hiến pháp 1959, về tổ chức để thực hiện quyền lập pháp, hành pháp và tư pháp cũng có những thay đổi so với Hiến pháp 1946, thể hiện ở những quy định Hiến pháp " Quốc hội là cơ quan quyền lực Nhà nước cao nhất của nước Việt Nam dân chủ cộng hòa" " Quốc hội là cơ quan duy nhất có quyền lập pháp của nước Việt Nam dân chủ cộng hòa", " Uỷ ban thường vụ Quốc hội là cơ quan thường trực của Quốc hội do Quốc hội bầu ra". Chủ tịch nước tách ra thành một định chế độc lập, không còn là người đứng đầu nhánh quyền lực hành pháp như quy định trong Hiến pháp 1946. Theo quy định Hiến pháp Chủ tịch nước có những quyền mang tính biểu tượng nhà nước như những người đứng đầu nhà nước của các quốc gia khác "thay mặt cho nước Việt Nam dân chủ cộng hòa về mặt đối nội và đối ngoại" và những quyền khác quy định tại các điều 63 , 64. Quyền hạn thực quyền của Chủ tịch nước gồm quyền " thống lĩnh lực lượng vũ trang toàn quốc, giữa chức vụ Chủ tịch Hội đồng quốc phòng" quyền triệu tập và chủ tọa Hội nghị chính trị đặc biệt". Còn Hội đồng Chính phủ được xác định là " Cơ quan chấp hành của cơ quan quề̀n lực Nhà nước cao nhất và là cơ quan hành chính nhà nước cao nhất của nước Việt Nam dân chủ cộng hòa".Từ những quy định này có thể nhận thấy, bắt đầu từ Hiến pháp năm 1959 đã hình thành cơ chế tập trung quyền lực nhà nước vào Quốc hội- cơ quan quyền lực nhà nước cao nhất, còn Chính phủ chỉ là cơ quan chấp hành của Quốc hội, về mặt hành chính thì Hội đồng Chính phủ chỉ là cơ quan hành chính nhà nước cao nhất. Những quy định này của Hiến pháp, như là sự tiếp thu những luận điểm cơ bản của C.Mác về tổ chức các cơ quan nhà nước theo mô hình Công xã Pari; theo mô hình chính quyền Xô viết do V.I. Lê nin khởi xướng và áp dụng ở nước Nga Xô viết. Theo quy định Hiến pháp quyền xét xử do Toà án nhân dân tối cao, các Tòa án nhân dân địa phương và Tòa án đặc biệt do Quốc hội thành lập để thực hiện.
Hiến pháp 1980 bên cạnh những kế thừa về quyền lực nhân dân ở các Hiến pháp trước, Hiến pháp năm 1980 đi theo hướng tập trung quyền lực vào cơ quan quyền lực nhà nước. Điều này thể hiện ở quy định: Quốc hội là cơ quan quyền lực nhà nước cao nhất, còn Hội đồng Bộ trưởng là Chính phủ nước Cộng hòa xã hội chủ nghĩa Việt Nam là cơ quan chấp hành và hành chính nhà nước cao nhất của cơ quan quyền lực nhà nước cao nhất. Như vậy, Chính phủ chỉ là cơ quan chấp hành và hành chính cao nhất của Quốc hội, chứ không phải cơ quan hành chính cao nhất của nước. Quan điểm tập quyền, tập trung quyền lực vào Quốc hội được thể hiện càng rõ với quy định: Quốc hội có thể đặt cho mình những nhiệm vụ, quyền hạn mới" và khi cần Quốc hội có thể trao cho Hội đồng Nhà nước và Hội đồng Bộ trưởng những nhiệm vụ, quyền hạn mới. Với cơ chế này có thể dẫn đến nhận thức là: quyền lực của Quốc hội không bị hạn chế bởi Hiến pháp, bởi pháp luật. Với mô hình này, có thể liên tưởng đến quan điểm " tất cả quyền lực" tập trung vào các Xô viết. Với cơ chế như vậy, việc phân công lao động quyền lực không rõ ràng, chế độ trách nhiệm tập thể được đề cao, còn trách nhiệm của cá nhân bị "mờ nhạt dần", cũng là nguyên nhân dẫn đến sự trì trệ trong hoạt động của toàn bộ máy nhà nước.

Hiến pháp 1992 (đã được sửa đổi, bổ sung năm 2001) bắt đầu có xu hướng giảm tính tập quyền, tập trung quyền lực nhà nước vào Quốc hội, thể hiện qua quan điểm "quyền lực nhà nước là thống nhất, có sự phân công, phối hợp giữa các cơ quan nhà nước trong việc thực hiện các quyền lập pháp, hành pháp, tư pháp”, nhưng vẫn giữ quan điểm "Quốc hội là cơ quan quyền lực nhà nước cao nhất, còn Chính phủ vừa là cơ quan chấp hành của Quốc hội và là cơ quan hành chính nhà nước cao nhất”, nhưng những quy định về “ đặc quyền" tự quyết định của Quốc hội không còn được quyết định như Hiến pháp năm 1980.

Hiến pháp năm 2013, thì sự phân công quyền lực được thể hiện rõ ràng hơn bởi quy định "Quyền lực nhà nước là thống nhất, có sự phân công, phối hợp, kiểm soát giữa các cơ quan nhà nước trong việc thực hiện các quyền lập pháp, hành pháp, tư pháp. Quốc hội là cơ quan đại biểu 
cao nhất của Nhân dân, cơ quan quyền lực nhà nước cao nhất của nước Cộng hoà xã hội chủ nghĩa Việt Nam. Quốc hội thực hiện quyền lập hiến, quyền lập pháp, quyết định các vấn đề quan trọng của đất nước và giám sát tối cao đối với hoạt động của Nhà nước"Chính phủ là cơ quan hành chính nhà nước cao nhất của nước Cộng hoà xã hội chủ nghĩa Việt Nam, thực hiện quyền hành pháp, là cơ quan chấp hành của Quốc hội "Tòa án nhân dân là cơ quan xét xử của nước Cộng hoà xã hội chủ nghĩa Việt Nam, thực hiện quyền tư pháp".

Từ những quy định của Hiến pháp, có thể khẳng định rằng, việc vận dụng quan điểm của chủ nghĩa Mác - Lê nin về tổ chức quyền lực nhà nước, ở khía cạnh chính trị, xã hội trong các Hiến pháp luôn khẳng định sự thống nhất của quyền lực nhà nước, nhưng về sự phân công quyền lực giữa lập pháp, hành pháp, tư pháp luôn có những thay đồi: sự phân công rõ nét nhất được thể hiện trong Hiến pháp 1946, bị mờ dẫn đi trong Hiển pháp 1959, đặc biệt là Hiến pháp 1980, đến Hiến pháp 1992 (sửa đổi, bổ sung năm 2001) thì tư tưởng về "sự phân công quyền lực" bắt đầu được thể hiện, và được thể hiện rõ hơn trong Hiến pháp năm 2013 và được bổ sung thêm cơ chế "kiểm soát giữa các cơ quan nhà nước trong việc thực hiện các quyền lập pháp, tư pháp".

Tóm lại: những luận điểm căn bản của chủ nghĩa Mác - Lê nin về nhà nước bao gồm rất nhiều nội dung: về bản chất giai cấp, bản chất xã hội của nhà nước, về đấu tranh giành chính quyền, lý thuyết đập tan bộ mày nhà nước cũ, về chuyên chính vô sản, sự lãnh đạo của Đảng cộng sản, của giai cấp công nhân trong xây dựng chủ nghĩa xã hội, về sự tiêu vong của nhà nước và nhiều vấn đề cốt lõi khác. Trong quá trình vận dụng những quan điểm này ở Việt Nam từ năm 1945 tới nay được thể hiện rõ nét nhất qua các bản Hiến pháp, được vận dụng trong thực tiễn cách mạng Việt Nam với những mức độ khác nhau, trong những chính sách, quyết sách đôi khi còn máy móc, giáo điều ít sáng tạo đã dẫn đến những hệ quả tiêu cực nhất định. Ngày nay trong điều kiện xây dựng nhà nước pháp quyền, kinh tế thị trường, hội nhập quốc tế ngày càng sâu rộng, đòi hỏi cần phải vận dụng những luận điểm của chủ nghĩa Mác - Lê nin về nhà nước một sách sáng tạo, không ngừng bổ sung những luận điểm đó với những nội dung mới, phù hợp với điều kiện mới.

\section{Tài liệu tham khảo}

[1] C.Mác và Ph.Ăngghen: Toàn tập, t.21, Nxb Chính trị quốc gia, Hà Nội, 1995, tr, 255.

[2] V.I. Lê nin, Toàn tập, tập 33, Nxb. Tiến bộ, Matxcơva,1976,tr.110.

[3] C.Mác và Ph.Ăngghen:Toàn tập, t.1, Nxb Chính trị quốc gia, Hà Nội, 2002, tr.585.

[4] V.I. Lê-nin: Toàn tập, t,33, Nxb Tiến bộ, Mátxcơ-va, 1981, tr 303

[5] V.I.Lê-nin:Sđd,t37,tr.122

[6] V.I. Lê nin, Toàn tập, t, 39, Nxb, Tiến bộ, Matxcơva,1977,tr.76

[7] V.I. Lê-nin: Toàn tập, t,34, Nxb Tiến bộ, Mátxcơ- va, 1976, tr 52

[8] V.I. Lê-nin: Toàn tập, t,21, Nxb Tiến bộ, Mátxcơ- va, 1980, tr 150

[9] C.Mác và Ph.Ăngghen: Toàn tập, t.20, Nxb Chính trị quốc gia - Sự Thật, Hà Nội, 1994, tr.253.

[10] V.I.Lênin: Toàn tập, Nxb Chính trị quốc gia, Hà Nội, 2006, t,35, tr.384.

[11] (11) (12) (13) V.I. Lênin: Toàn tập, Nxb Tiến bộ, Mát-xcơ-va, 1976, t 33, tr 101-102,tr. 28, tr.111

[12] (14 )(15) V.I. Lê-nin: Toàn tập, Nxb Tiến bộ, Mát-xcơ-va, 1981, t 31, tr 356, tr.356.

[13] (16).V.I. Lê-nin: Toàn tập, Nxb Tiến bộ, Mátxcơ-va, 1978, t 43, tr 380

[14] (17).V.I. Lê-nin: Toàn tập, Nxb Tiến bộ, Mátxcơ-va, 1981, t 31, tr 356.

[15] (18).V.I. Lê-nin: Toàn tập, Nxb Tiến bộ, Mátxcơ-va, 1978, t 33, tr 109.

[16] (19) (20) (21) C. Mác - Ph.Angghen. Tuyển tập. T.1. NXB. Sự thật. H. 1980. tr. 315;tr. 407; tr. 405.

[17] (22)Mác- Ph. ănggen Tuyển tập. NXB. Sự thật. H. 1970.tr. 627.

[18] (23) V. I. Lênin. Toàn tập. T. 38. NXB. TB. M. 1978. tr. 59. 